\title{
Influence of Chinese natural philosophy on the formation of Korean anthroponyms
}

\author{
Baginskaya Marina Vladimirovna ${ }^{1,{ }^{*}}$, Li Ekaterina Vadimovna ${ }^{1}$, Kalish Elena Evgenievna ${ }^{1}$ \\ ${ }^{1}$ Irkutsk State University, Department of Oriental and Regional Studies of the Asia-Pacific Region, 664025, 8-Lenin str., Russia
}

\begin{abstract}
The purpose of the article is to provide a complex scientific description of traditional principles of Korean anthroponyms formation. An anthroponymic system is the reflection of national culture, therefore its description cannot be limited to linguistic analysis only, it should be carried out with the reference to ethnology, history, philosophy, theology and other disciplines. The history and culture of Korean peninsula countries is tightly connected with the history and culture of China with the onomastic system being no exception. Traditional principles of formation of Korean anthroponyms have Chinese origin. Basic philosophic concepts that influenced the name giving principles in the Korean language are the theory of the unity of the opposites Yin and Yang (음양 - 陰陽) and concept of five elements or Wuxing (오행 - 표워). It is believed that the main ideas of each of these theories being realized in the signs of a name have an impact on a person's fate and define a person's character. According to Yin and Yang theory, every sign in a name depending on its constituent elements is in correlation with one of the two opposites, male or female principles, light or dark, etc. Ideally a name should combine Yin and Yang, while the dominance of one principle and the absence of the other make the name lacking harmony. Wuxing concept is based on the assumption that every sign in a name is related to one of the fifth primary elements: fire, water, air, earth and metal. According to this theory a person's name should have such a combination of elements that would bring harmony and not destruction. Initially both concepts were applied to ideographic signs and characters that constituted a traditional Korean name, nevertheless these principles are observed nowadays in the creation of Korean names without characters usage. This research has been carried out within the grant agreement "Establishment of the Center for Korean Studies at Irkutsk State University" with the support of the Korea International Exchange Foundation (KF-2021).
\end{abstract}

\section{Introduction}

A rising interest to widely differing aspects of oriental languages studies results in the need to fill some kind of gap in the sphere of anthroponymic onomasticon. It is necessary to study the peculiarities of creation of some Korean anthroponyms as well as to analyze the factors that have influenced the name giving principles in Korea.

The purpose of the article is to provide complex scientific description of traditional principles of Korean anthroponyms formation.

The study of the anthroponymic system of any language allows disclosing national identity, comprehending the mindset and character of the people of a particular ethnic group. An anthroponym has a complex inner structure and bears the imprint of the culture time; therefore, its study should not be done within the linguistics only. A proper name is in the first instance a storage of national cultural information, which is formed under the influence of various aspects

\footnotetext{
* Corresponding author: mvbaginskaya@list.ru
}

including extralinguistic factors. Therefore, the description of anthroponymic systems of different cultures is the issue of complex nature and should be considered within linguistics, ethnology, history, philosophy, theology and a number of other disciplines.

It is a matter of fact that an anthroponym incorporates various cultural senses and values, forming in such a way a linguocultural potential. The latter implies that a name possesses transcendent features related to the material cultural sphere and culture specific reference experience.

The history and culture of Korean peninsula countries at almost all times has been tightly connected with the history and culture of China with the onomastic system being no exception.

The existing works on the onomastics of China (from the description of formal features of names to mythopoetic traditions expressed in Chinese name giving practice) enable to make the conclusion about the existence of cultural uniformity in anthroponymic systems of China and Korea [1]. It may be claimed that 
traditional principles of formation of Korean anthroponyms have Chinese origin.

\section{Results and Discussion}

From the viewpoint of their origin Korean, personal names are divided into two big groups: originally Korean names (보름, 사랑, 이슬, 한길 ) and Sino-Korean names that have been created on the basis of Chinese characters (재인 (在寅), 승환 ( 承桓 ), 희순 ( 喜洵 )).

It is worthy to note, that Chinese principles of name giving have influenced the formation of not only SinoKorean but also originally Korean anthroponyms.

The basic philosophic concepts that influenced the principles of name giving in the Korean language are the theory of unity of the opposites Yin and Yang (음양 陰陽) and the concept of five elements (오행 - 五行). It is believed that the main ideas if these theories being realized in the signs of a name influence a person's fate and define a person's character.

The essence of the natural philosophy of Yin and Yang is that all things in existence appear in the result of the opposite's interaction, light and dark, male and female principles, life and death, etc.

According to this theory a name like all leaving creatures in the world should also be comprised of Yin and Yang elements and only in this case the name may be considered a good one and harmonic, while its owner will manage to succeed.

In the name giving this concept is realized in the following way. An odd number of strokes in the name of a sign $(1,3,5,7,9)$ is related to Yang, and even number to Yin. It is considered that having only Yang elements in a person's name may result in problems with female relatives: mother, wife or daughter.

A person who has such kind of name is destined for loneliness as he/she would not be able to find a partner or a mate in society. On the other hand, if a name has only Yin elements, this does not bring good luck to its owner either since the presence of purely female principles and absence of male power will not allow its owner to reach success [2].

The compliance or non-compliance with the principles of Yin and Yang harmony is illustrated by the examples of names depending on the signs that compose them and is presented in Table 1 .

Table 1. Yin and Yang distribution in the names according to the number of strokes.

\begin{tabular}{|l|ll|ll|l|l|}
\hline 김희수 & 리성민 & 박 승화 & 최정 & 허준 \\
\hline 김 술 8 & 리 李 & 7 & 박 朴 & 6 & 최 崔 & 허 許 \\
& 0 & & $\bullet$ & & 11 ○ & $11 \circ$ \\
& & & & & & \\
& & & & & & \\
\hline
\end{tabular}

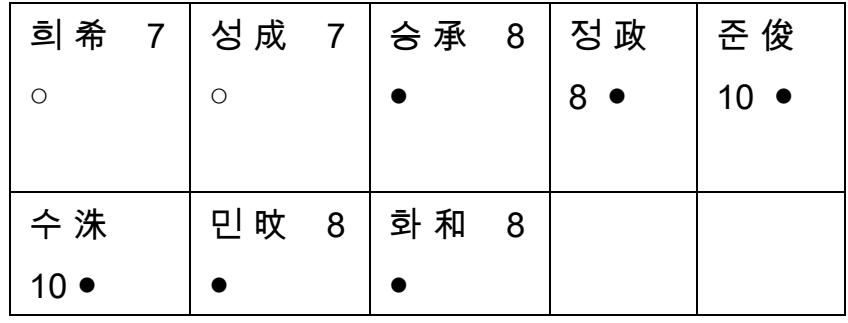

In the first name 김희수 (金希洙) a combination of Yin and Yang elements looks like this: 8 (Yin) -7 (Yang) - 10 (Yin). This alteration of signs points at the harmony of Yin and Yang in the name.

In the second name 리성민 (李成旼) a combination of elements 7 (Yang) - 7 (Yang) - 8 (Yin) demonstrates only some symbiosis of Yin and Yang.

In the third name 박승화 (朴承和) a combination of elements is presented in the following way: 6 (Yin) -8 (Yin) -8 (Yin). It is obvious that such combination of elements does not meet the requirements of Yin and Yang harmony, since there is no sign with an odd number of strokes that would add Yang energy.

The fourth and the fifth names consisting of two signs illustrate a complete harmony of Yin and Yang because these elements are equally presented [3].

Originally Yin and Yang concept was exclusively related to ideographic signs and characters that constituted a traditional Korean name.

Nevertheless still nowadays these principles are observed in the creation of originally Korean names that have no connection with characters.

Thus, syllables with padchims are associated with Yang energy, syllables without padchims - with Yin energy.

It may be assumed that this principle is realized in relation with the euphony.

Since Yang energy is related to the syllables with padchims or closed syllables, actualization of the male principle is taking place at a phonetic level. In fact, a closed syllable sounds shorter and rougher than an open syllable that ends in a vowel and may be «drawled» as long as needed.

Such women's names as 미화, 미현, 지우 demonstrate this peculiarity. 미화 and 지우 names consist of open syllables and therefore sound softer, more melodiously and delicately, thus associating with the qualities inhering in women.

On the contrary, 미현 and 명훈 names are partially or completely composed of closed syllables and therefore sound shorter and rougher associating with truly men's qualities.

It is also very important to consider how the name is coupled with the last name. A combination of alternating closed and open syllables sounds quite harmonically. For example: 김지우, 하명훈, 정미현, etc. [3].

The Korean alphabet vowels are divided into «light» and «dark» ones depending on their shapes and stroke order. Thus, letters $\vdash, k, \perp, \Perp \Perp$, 나, 내, 니 are 
considered light ones and are related to Yang energy,

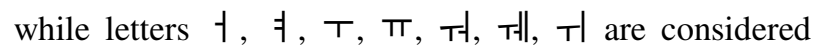
dark ones and are referred to Yin energy. This fact is also taken into consideration in choosing a name.

As previously mentioned, the number of strokes in signs is important when making a choice of these ideographic signs for a name.

The use of modern traditional Korean names does not downplay the importance of the principle of the even/odd number of strokes in a letter.

The number of strokes in the letters of Korean alphabet is presented in Table 2 .

Table 2. The number of strokes in the consonants and vowels of the Korean alphabet.

\begin{tabular}{|c|c|c|c|}
\hline \multicolumn{2}{|c|}{ Consonants } & \multicolumn{2}{|c|}{ Vowels } \\
\hline Letter & $\begin{array}{l}\text { Strokes } \\
\text { number }\end{array}$ & Letter & $\begin{array}{l}\text { Strokes } \\
\text { number }\end{array}$ \\
\hline $\begin{array}{l}\neg \\
\llcorner \\
0\end{array}$ & 1 & $\begin{array}{c}- \\
1\end{array}$ & 1 \\
\hline $\begin{array}{l}\text { ᄃ } \\
\text { 人 } \\
\text { ᄌ } \\
7 \\
77\end{array}$ & 2 & $\begin{array}{l}1 \\
-1 \\
+ \\
- \\
-1\end{array}$ & 2 \\
\hline 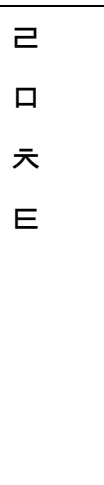 & 3 & $\begin{array}{l}F \\
A \\
\Perp \\
\pi \\
H \\
-1 \\
\perp \\
+1\end{array}$ & 3 \\
\hline $\begin{array}{l}\text { ㅂ } \\
\bar{I} \\
\text { ㄷ } \\
\text { 从 }\end{array}$ & 4 & $\begin{array}{l}\text { 月 } \\
\# \# \\
\text { 겨 }\end{array}$ & 4 \\
\hline 뽀 & 8 & $\begin{array}{l}\text { 계 } \\
\text { 내 }\end{array}$ & 5 \\
\hline
\end{tabular}

As demonstrated in Table 2 the number of strokes for consonant letters is not more than eight and for vowel letters it is not more than five which makes the choice of signs in accordance with the strokes number more limited in comparison with Sino-Korean names.

Nevertheless modern name giving manuals usually mention this rule.
Alongside with Yin and Yang theory a philosophic concept of 5 elements or Wuxing, one of the fundamental categories of Chinese philosophy, had a great influence on the formation of name giving principles in Korea.

Wuxing is a universal classification scheme according to which all cosmic parameters have a fiveelement structure. Wuxing in its so called cosmogonic order is «water», «fire», «metal», «wood» and «earth». In interaction these elements may either complement or otherwise destroy each other.

Consequently, a person's name should have a combination of elements that would generate harmony and complementarity, but not destruction [4].

When choosing signs for a name. several criteria are taken as the guidelines in accordance with the concept of 5 elements.

Thus, the basic component in the signs of a name is graphical one, and phonetic component is the main one at the sound level.

The compatibility of this or that sign (character) with a particular element is determined by the number of strokes in this character. $1-2$ strokes are compatible with «wood» element, $3-4$ strokes - with «fire» element, $5-6$ strokes - with «earth» element, $7-8$ strokes - with «metal», $9-10$ strokes - with «water». If a character has more than 10 strokes, the number is reduced by 10 or a multiple of 10 .

For example, if a character consists of 22 strokes, it is necessary to subtract 20 from 22 to define a compatible element. Number 2 determines the element that is compatible with the sign.

This may be presented in the Table below.

Table 3. The compatibility of signs of name with five elements.

\begin{tabular}{|c|c|c|c|c|c|}
\hline Element & $\begin{array}{c}\text { 木 } \\
\text { Wood }\end{array}$ & $\begin{array}{c}\text { 火 } \\
\text { Fire }\end{array}$ & $\begin{array}{c}\text { 土 } \\
\text { Earth }\end{array}$ & $\begin{array}{c}\text { 金 } \\
\text { Metal }\end{array}$ & $\begin{array}{c}\text { 水 } \\
\text { Water }\end{array}$ \\
\hline $\begin{array}{c}\text { Strokes } \\
\text { number in } \\
\text { a sign }\end{array}$ & $1-2$ & $3-4$ & $5-6$ & $7-8$ & $9-$ \\
& & & & 10 \\
\hline
\end{tabular}

A phonetic criterion is a fundamental one at the sound level. According to this theory all sounds pronounced by a human comply with some philosophic idea and every sound is compatible with this or that world element.

Korean scholars note that consonant sounds of the Korean language depending on their position in a word are compatible with one of the fifth elements [4]. This correlation is presented in Table 4.

Table 4. The compatibility of consonant sounds of the Korean language with five elements.

\begin{tabular}{|c|c|c|c|c|c|}
\hline Element & $\begin{array}{c}\text { 木 } \\
\text { Wood }\end{array}$ & $\begin{array}{c}\text { 火 } \\
\text { Fire }\end{array}$ & $\begin{array}{c}\text { 土 } \\
\text { Earth }\end{array}$ & $\begin{array}{c}\text { 金 } \\
\text { Metal }\end{array}$ & $\begin{array}{c}\text { 水 } \\
\text { Water }\end{array}$ \\
\hline Consonant & $\neg$ & ட & ○ & 人 & ロ \\
sounds & フ & ᄃ & こ & ス & 日 \\
\hline
\end{tabular}




\begin{tabular}{|c|c|c|c|c|c|}
\hline & & $\begin{array}{l}\text { 己 } \\
E\end{array}$ & & 天 & 표 \\
\hline Articulation & back & front & glottal & dental & labial \\
\hline
\end{tabular}

A combination of elements in a name has a special meaning, since their interaction complies with the particular rules. In water and earth interaction, for example, earth sucks all water and water cannot enforce all its power, therefore a name with this combination is considered unfortunate and lacking harmony. In earth and metal interaction, the earth solidifies and creates metal again, and the name which has this combination of elements is considered a good one.

In other words, the movement from one element to another should be made along the circle clockwise. This principle violation leads to harmony disturbance.

It may be presented in the figure below.

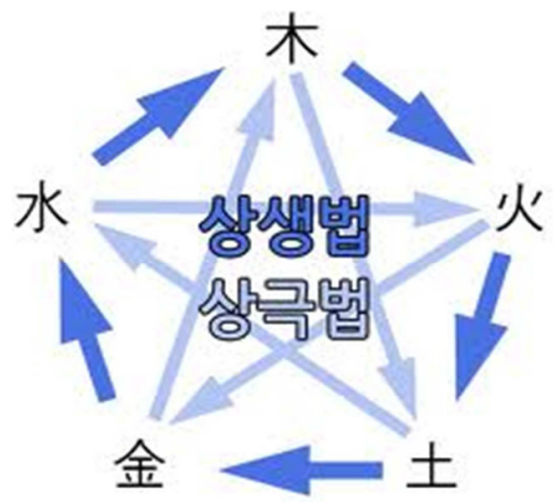

Fig. 1. Interaction of 5 elements.

The movement along the outside circle demonstrates the following order of favorable elements interaction (사생법):

목생화木生火 - wood generates fire;

화생토火生土 - fire generates earth;

토생금土生金 - earth generates metal;

금생수金生水 - metal generates water;

수생목水生木 - water generates wood.

Arrows inside the circle, on the other hand, demonstrate the disturbance of harmony:

목극토木剋土 - wood destroys earth;

토극수土剋水 - earth destroys water;

수극화水兛火 - water destroys fire;

화극금火攰金 - fire destroys metal;

금극목金剋木 - metal destroys wood.

When choosing signs of a name several factors should be considered: first, graphic compatibility of each sign with a particular element; second, phonetic compatibility of each sign with a particular element; third, interaction of these elements within the name.

As it was shown above, compatibility of elements that match graphic and phonetic criteria of the signs constituting a name may be considered positive, neutral or negative. Thus, for example, combinations 火土金 «fire - earth - metal», 金水木 «metal - water - tree», 木 木木 «tree - tree - tree» are considered positive, combinations 金火土 《metal - fire - earth», 火木土 «fire - wood - earth», 水土金 «water - earth - metal» neutral, 火木土 «fire - wood - earth», 土木水 «earth wood - water» and 金水木《metal - water - wood» negative ones [5].

Both categories of Yin Yang and Wuxing that have been discussed above are referred to numerological objects, which are the «the basic ontological images of symbols and numbers». A. I. Kobzev rightly remarks, that numerology for China was an analogue of science and logic in Europe. Numerological elements were presented by complexes of numbers and geometric structures that were symbolically or associatively connected with each other, while the category of number was the basic element of Nature (word order) [6].

China in its turn was the main cultural center of Eastern Asia and for many centuries had a tremendous impact on the culture of nearby states including Korea. Hence, there is the consistency not only in the sphere of culture in general, but also in the sphere of name giving in particular.

\section{Conclusion}

For centuries Korea has been under the influence of China and has adopted among other things traditional name giving principles. Basic philosophic concepts that influenced the name giving principles in the Korean language are the theory of the unity of the opposites Yin and Yang and concept of five elements or Wuxing.

The main ideas of each of these theories being realized in the signs of a name have an impact on a person's fate and define a person's character. According to Yin and Yang theory, every sign in a name is in correlation with one of the two opposites, male or female principles, light or dark, etc.

An ideal name should harmonically combine Yin and Yang, otherwise a person who has this name will not be happy and successful. Wuxing concept is based on the assumption that every sign in a name is related to one of the fifth primary elements: fire, water, air, earth and metal.

According to this theory a person's name should have such a combination of elements that would bring harmony and not destruction.

Initially both concepts were applied in the creation of names on the basis of characters, but nowadays these principles are observed in the creation of Korean names with the use of Korean alphabet hangul. 


\section{References}

1. E.A. Khamaeva, Anthroponyms in the Onomastic System of Mythological Type (2012)

2. Mantae Kim, Studies in Religion (The Journal of the Korean Association for the History of Religions), 65, pp. 151-186 (2011)

3. Haesong Choi, Legitimate modern naming (2012)
4. Ikki Kwon, Korean studies, 162, pp. 181-214 (2021)

5. Ssngchun Shin, Changgun Jung, Jingu Jeong, Asiapacific Journal of Multimedia Services Convergent with Art, Humanities, and Sociology, Vol.7, No. 6, pp. 671-680 (2017)

6. A.I. Kobzev, Society and Government in China: XXXIV Scientific Conference

(2004) 